\title{
Effects of Dairy Cow Diet Forage Proportion on Duodenal Nutrient Supply and Urinary Purine Derivative Excretion
}

\author{
J. M. Moorby, ${ }^{11}$ R. J. Dewhurst,$\dagger^{2}$ R. T. Evans, ${ }^{*}$ and J. L. Danelón† \\ *Institute of Grassland and Environmental Research, Plas Gogerddan, Aberystwyth, SY23 3EB, UK \\ †Faculty of Agronomy, University of Buenos Aires, Avenida San Martín 4453, (C1417 DSQ) Buenos Aires, Argentina
}

\begin{abstract}
Four mature Holstein-Friesian dairy cows were used in a $4 \times 4$ Latin square change-over design experiment made up of four 4-wk periods to investigate the relationship between microbial protein flow to the duodenum and excretion of purine derivatives (PD) in the urine. Four dietary treatments based on ad libitum access to ryegrass silage were offered, with a standard dairy concentrate included at different forage:concentrate (F:C) ratios, calculated on a dry matter basis: $80: 20$, $65: 35,50: 50$, and 35:65. Feed intakes increased as the proportion of concentrate in the diet increased, despite a concurrent decrease in silage intake. Increased feed intake led to increased nutrient flow to the duodenum. Milk yields increased as the diet F:C ratio decreased, with cows offered the 35:65 diet yielding nearly $8 \mathrm{~kg} / \mathrm{d}$ more milk than cows offered the 80:20 diet; the concentrations of milk fat decreased and milk protein increased with a decreasing $\mathrm{F}: \mathrm{C}$ ratio. Purine derivative excretion in the urine increased with an increasing proportion of concentrate in the diet, and there was a strong linear relationship between total PD excretion (allantoin and uric acid) and microbial $\mathrm{N}$ flow to the duodenum: microbial $\mathrm{N}(\mathrm{g} / \mathrm{d})=19.9+0.689 \times$ total $\mathrm{PD}$ $(\mathrm{mmol} / \mathrm{d}) ; \mathrm{R}=0.887$. This strengthens the case for using $\mathrm{PD}$ excretion as a noninvasive marker of microbial protein flow from the rumen in dairy cows.
\end{abstract}

Key words: dairy cow, nitrogen partitioning, purine derivative, rumen function

\section{INTRODUCTION}

Microbial protein synthesis in the rumen is often the main component of the metabolizable protein supply in dairy cows (NRC, 2001). Many studies have estimated microbial protein flow from the rumen using inert marker techniques and cannulated animals. However,

\footnotetext{
Received September 14, 2005.

Accepted April 28, 2006.

${ }^{1}$ Corresponding author: jon.moorby@bbsrc.ac.uk

${ }^{2}$ Current address: Agriculture and Life Sciences Division, Lincoln University, Canterbury, New Zealand.
}

these invasive techniques are difficult to carry out and have not led to robust models for predicting microbial protein synthesis as part of rationing models (Titgemeyer, 1997; Dewhurst et al., 2000a), even though models that are currently used to predict microbial protein synthesis in this way are successful in most production settings. We have focused on less-invasive and noninvasive techniques for estimating microbial protein synthesis because they have the potential for development of novel diagnostic tests for commercial application of research. Urinary excretion of purine derivatives (PD) offers a way of estimating microbial $\mathrm{N}$ flow from the rumen (Johnson et al., 1998; González-Ronquillo et al., 2004) because most feed purines are broken down by rumen microbes (McAllan and Smith, 1973). Therefore, the majority of purines absorbed from the small intestine, degraded, and excreted in the urine are of microbial origin (McAllan, 1980). Previous studies have investigated the effects of a range of supplements and forage types (Johnson et al., 1998) and feed restrictions (González-Ronquillo et al., 2004), but not the effects of widely different forage-to-concentrate $(\mathbf{F}: \mathbf{C})$ ratios on the relationship between urinary PD excretion and duodenal microbial protein flow. It is possible that changes in purine metabolism would invalidate the use of urinary $\mathrm{PD}$ excretion for comparisons of such widely different diets.

We hypothesized that decreasing the $\mathrm{F}: \mathrm{C}$ ratio of the diet of dairy cows would increase nutrient intake and generate an increased microbial protein flow to the duodenum that in turn would increase the excretion of $\mathrm{PD}$ in the urine. Therefore, the objective of this experiment was to investigate this relationship, stimulating differences in microbial protein yield from the rumen by offering diets differing in a wide range of $\mathrm{F}: \mathrm{C}$ ratios to alter feed intake and the supply and utilization of nutrients in the rumen.

\section{MATERIALS AND METHODS}

\section{Cows and Experimental Design}

All procedures used in this experiment were licensed and regulated by the UK Home Office under the Ani- 
Table 1. Ingredients of the concentrate feed used in the experiment

\begin{tabular}{ll}
\hline Ingredient & $\begin{array}{l}\text { Total } \\
\text { content, } \\
\% \text { as fed }\end{array}$ \\
\hline Wheat & 30 \\
Rapeseed meal & 15 \\
Corn gluten feed & 15 \\
Extracted linseed meal & 12 \\
High protein extracted sunflower meal & 11 \\
Sugar beet pulp & 6 \\
Molasses & 6 \\
Extracted palm kernel meal & 2 \\
Other ${ }^{1}$ & 3 \\
\hline
\end{tabular}

${ }^{1}$ Vegetable oil, calcium carbonate, vitamin and mineral premix (7,500 IU of vitamin $\mathrm{A} / \mathrm{kg}, 2,250 \mathrm{IU}$ of vitamin $\mathrm{D}_{3} / \mathrm{kg}, 10 \mathrm{IU}$ of $\alpha-$ tocopherol $/ \mathrm{kg}, 0.30 \mathrm{mg}$ of sodium selenite/ $\mathrm{kg}$, and $40 \mathrm{mg}$ of cupric sulfate/kg), salt, calcined magnesite.

mals (Scientific Procedures) Act of 1986. Four HolsteinFriesian dairy cows previously prepared with simple cannulas in the rumen (Bar-Diamond, Parma, ID) and proximal duodenum in midlactation [starting at a mean of 90 (SD = 33.6) DIM; mean BW of $627 \mathrm{~kg}$ ( SD = 53.3)] were used in a $4 \times 4$ Latin square change-over experimental design with 28 -d periods. The first $2 \mathrm{wk}$ of each period were used for adaptation to the diets, and the last 2 wk were used for measurements. Animals were housed in individual stalls, and had free access to fresh water and a trace mineral lick (Red Baby Rockies, Tithebarn Ltd., Cheshire, UK). Cows were milked twice per day, at approximately 0800 and $1600 \mathrm{~h}$, and all milk yields were recorded.

\section{Dietary Treatments}

Four dietary treatments were used, comprising the same second-cut ryegrass silage and standard dairy concentrate (Table 1), and were offered at $4 \mathrm{~F}$ :C ratios (DM basis): 80:20, 65:35, 50:50, and 35:65. Diet F:C ratios were achieved by measuring ad libitum silage DMI on a daily basis (silage was offered to allow at least $10 \%$ refusals), and allocating the appropriate amount of concentrate to each animal based on a rolling average of their silage DMI from the previous $3 \mathrm{~d}$ of the experiment. To reduce the chance of rumen acidosis, sodium bicarbonate was added to all diets at the rate of approximately $1.7 \%$ of total DM, mixed in with the concentrate ration, which was offered in 2 equal portions per day, one at each milking. At the start of each experimental period, concentrate allocations were gradually changed to the new F:C ratio in steps of $25 \%$ of the difference between the previous and new quantities of concentrate over the course of $6 \mathrm{~d}$, with cows being offered the intermediate allocations for $2 \mathrm{~d}$ each.

\section{Measurements and Sample Analysis}

Silage and concentrate samples were collected and composited over each week of the experiment, stored frozen at $-18^{\circ} \mathrm{C}$, and freeze-dried prior to analysis according to the methods described by Dewhurst et al. (2000b).

The first $6 \mathrm{~d}$ of the third week of each experimental period were used for the collection of urine and feces for diet digestibility, $\mathrm{N}$ partitioning, and urinary $\mathrm{PD}$ output measurements. Samples for the calculation of diet digestibility and $\mathrm{N}$ partitioning were taken as described by Moorby et al. (2000) from total daily productions of urine and feces collected using an externally applied collection apparatus. Diet ME (Mcal/kg) density was calculated as $0.0037 \times$ digestibility of the OM expressed as a proportion of the DM (Agricultural and Food Research Council, 1993). Daily collections of urine were preserved by acidification (using $1.5 \mathrm{~L}$ of $2 \mathrm{M}$ sulfuric acid) and subsampled (1\% of daily collection) to produce a composite sample for each animal. Feces were also subsampled (5\% of daily production) daily after thorough mixing, and composited. Urine and feces were stored at $4^{\circ} \mathrm{C}$ during the week, and approximately 100-mL subsamples of the mixed composite urine samples were stored frozen for analysis. A further $100 \mathrm{~mL}$ of mixed composited urine was diluted with $400 \mathrm{~mL}$ of tap water and stored frozen for PD analysis. Urinary PD were measured as described by Dewhurst et al. (1996). Milk samples were taken (1\% of milk produced from a.m. and p.m. milkings) and stored at $4^{\circ} \mathrm{C}$ between milkings, and were composited over the course of the 6 -d measurement period. The $\mathrm{N}$ concentrations of milk, feces, and urine were measured as described by Moorby et al. (2000), and the milk CP concentration was calculated as $\mathrm{N} \times 6.38$. Milk samples were analyzed for fat and lactose by near-infrared spectroscopy (National Milk Records, Yeovil, Somerset, UK).

The final week of each experimental period was used for the measurement of digesta flow from the rumen as described by Dewhurst et al. (2003), with analysis of samples as described by Dewhurst et al. (2000b). Rumen $\mathrm{pH}$ was recorded manually with a benchtop $\mathrm{pH}$ meter (model EW-59003-25; Cole-Parmer Instrument Co. Ltd., London, UK) using strained digesta at 0900 , $1000,1100,1300,1500,1700$, and $2200 \mathrm{~h}$, and the samples taken at these times were analyzed for concentrations of ammonia N and VFA. During the digesta flow measurement periods, ytterbium acetate (mean $584 \mathrm{mg}$ $\mathrm{Yb} / \mathrm{d} ; \mathrm{SD}=41.0)$ and chromium ethylene diamine tetraacetic acid (CrEDTA; mean 2,562 $\mathrm{mg}$ of $\mathrm{Cr} / \mathrm{d}$; $\mathrm{SD}=$ 272.2) were continuously infused into the rumen as particulate and liquid markers, respectively, to allow estimation of digesta flows at the duodenum (Faichney, 
1980). Ytterbium and CrEDTA concentrations in duodenal digesta samples were measured by atomic absorption spectrophotometry (Siddons et al., 1985). Samples of duodenal digesta were taken prior to infusion of markers in each experimental period to assess background concentrations of digesta markers. Solid- and liquid-associated bacteria were separated from digesta as described by Dewhurst et al. (2003) and the average composition was used for calculations of microbial $\mathrm{N}$ content in duodenal digesta. The microbial $\mathrm{N}$ concentration of digesta was calculated using the ratio of microbial $\mathrm{N}$ to cytosine, which was determined in rumen microbes and duodenal digesta according to the method of Cozzi et al. (1993) using HPLC (LDC/Milton Roy, Ivyland, PA). Nonammonia N concentrations of duodenal digesta were calculated as the difference between total $\mathrm{N}$ and ammonia $\mathrm{N}$ in duodenal digesta; ammonia $\mathrm{N}$ in duodenal digesta was analyzed using a test kit (No. 66-50; Sigma-Aldrich Co. Ltd., Poole, UK). Undegraded feed $\mathrm{N}$ was estimated by subtracting microbial $\mathrm{N}$ and endogenous N (estimated as $2.8 \mathrm{~g} / \mathrm{kg}$ of DMI; Bartram, 1987) from nonammonia $\mathrm{N}$ flow to the duodenum.

\section{Statistical Analysis}

Data were analyzed using the statistical software Genstat for Windows (Lawes Agricultural Trust, 2000). Analysis of variance was used, with a blocking structure of experimental period $\times$ cow, with orthogonal polynomial contrasts (with treatment spacing based on actual $\mathrm{F}: \mathrm{C}$ ratios) in the treatment structure to investigate the response of each variable to decreasing $\mathrm{F}: \mathrm{C}$ ratio. The linear relationship between microbial $\mathrm{N}$ flow to the duodenum and total PD excretion in urine was carried out using Bartlett's 3-group regression method (Bartlett, 1949) because the error variances of the measurements on both axes were unknown. Correlation coefficients $(R)$ were calculated among the measurements of microbial $\mathrm{N}$ flow, total urinary PD excretion, and total DMI. Paired $t$-tests were carried out on DMI data collected in each of the $\mathrm{N}$ partitioning-digestibility and duodenal digesta flow measurement weeks to compare the data collected in each week. Milk production data are reported for the $\mathrm{N}$ partitioning-digestibility measurement week only. Statistical significance was declared at $P<0.05$.

\section{RESULTS}

\section{Feed Intake and Milk Production}

The mean composition of the silage and concentrate feed offered during the experiment is given in Table 2. The mean actual F:C ratios of the diets offered are given in Table 3 and were very close to the specified ratios.
Total DMI increased linearly $(P<0.001)$ with a decreasing $\mathrm{F}$ :C ratio, and there was a small $(P<0.01)$ decrease in the ad libitum consumption of silage DM as the concentrate portion of the diet increased. Concentrate intake increased $(P<0.001)$, as expected. Organic matter, $\mathrm{N}, \mathrm{NDF}$, and starch intakes all increased $(P<0.05)$ with increasing feed intakes. There were slight differences $(P$ $>0.05$ ) in the DMI data collected for each animal in each of the 2 collection weeks in each experimental period, but the effects of the F:C ratio were the same in each week. The ME densities of the 4 diets tended to increase as the concentrate portion of the diet increased, with values of $2.35,2.40,2.41$, and $2.45 \mathrm{Mcal} /$ $\mathrm{kg}$ DM [standard error of the differences of the means $($ SED $)=0.041, P<0.1]$ for treatments $80: 20,65: 35$, 50:50, and 35:65, respectively. Metabolizable energy intakes increased linearly $(P<0.001)$ as feed intake increased.

Milk yields were significantly increased with the decreasing $\mathrm{F}$ :C ratio in a linear fashion $(P<0.001)$, with a difference of nearly $8 \mathrm{~kg}$ of milk/d between the 2 extremes in the $\mathrm{F}: \mathrm{C}$ ratio. There was no difference between treatments in the quantity of milk yielded per kilogram of feed DMI, although the quantity of milk yielded per kilogram of concentrate DMI decreased ( $P$ $<0.001$ ) as the proportion of concentrate in the diet increased. The concentrations of milk CP $(P<0.001)$ and lactose $(P<0.05)$ increased, whereas the milk fat concentration decreased $(P<0.05)$ with a decreasing $\mathrm{F}: \mathrm{C}$ ratio, and there tended $(P<0.1)$ to be a quadratic effect of treatment on milk fat concentrations, with the highest fat concentrations being observed with treatment 65:35. The yields of milk fat, protein, and lactose all increased linearly $(P<0.01)$ with the decreasing $\mathrm{F}: \mathrm{C}$ ratio.

\section{Feed Digestibility, Rumen Fermentation, and Digesta Flows}

Apparent rumen digestibility of $\mathrm{DM}, \mathrm{OM}, \mathrm{N}$, and starch were all unaffected by treatment (Table 4). However, the apparent digestibility of NDF was reduced ( $P$ $<0.05)$ with increasing concentrate intake. Thus, with increasing feed intakes, the apparent digestion of DM, $\mathrm{OM}$, and starch in the rumen increased $(P<0.01)$, whereas that of NDF was unaffected by treatment. The apparent digestibility and digestion of $\mathrm{N}$ in the rumen was close to zero, with no significant differences among treatments. Similarly, true digestibility of $\mathrm{N}$ in the rumen was not affected by treatment $(P>0.05)$, although the quantity of dietary $\mathrm{N}$ digested in the rumen increased $(P<0.01)$ with increasing feed intake.

Nutrient flows to the duodenum all increased linearly $(P<0.01)$ with a decreasing F:C ratio, except for the 
Table 2. Mean chemical composition of the grass silage and concentrate feed offered during the experiment

\begin{tabular}{lllll}
\hline Item & $\begin{array}{l}\text { Silage } \\
(\mathrm{g} / \mathrm{kg} \text { of } \mathrm{DM})\end{array}$ & $\mathrm{SE}^{1}$ & $\begin{array}{l}\text { Concentrate } \\
(\mathrm{g} / \mathrm{kg} \text { of DM) }\end{array}$ & $\mathrm{SE}^{1}$ \\
\hline $\mathrm{DM}, \mathrm{g} / \mathrm{kg}$ & 264 & 6.5 & 876 & 3.9 \\
$\mathrm{OM}$ & 926 & 0.6 & 916 & 1.1 \\
$\mathrm{CP}$ & 122 & 2.9 & 228 & -5 \\
Ammonia, g of N/kg of total N & 74 & 5.1 & - & 4.1 \\
NDF & 619 & 3.3 & 248 & 2.3 \\
ADF & 370 & 2.4 & 120 & 3.7 \\
Water-soluble carbohydrates & 19.0 & 2.6 & 59 & 5.5 \\
Starch & - & - & 221 & 0.120 \\
Acid hydrolysis ether extract & - & 0.043 & 50 & - \\
Gross energy, Mcal/kg & 4.95 & 0.03 & - & - \\
pH & 3.7 & 3.8 & - & - \\
Lactic acid & 104 & 1.03 & - & - \\
Acetic acid & 9.4 & 0.073 & - & - \\
Propionic acid & 0.65 & 0.146 & - & - \\
$n$-Butyric acid & 0.57 & & & \\
\hline
\end{tabular}

${ }^{1} \mathrm{n}=8$.

flow of undegraded dietary $\mathrm{N}$, which only tended to increase $(P<0.1)$. The difference in the flow of NDF in animals offered the 50:50 and 35:65 treatments was marginal, giving a nonsignificant quadratic effect $(P$ $<0.1$.

Apparent whole-tract digestibility of DM, OM, and $\mathrm{N}$ all increased linearly $(P<0.05)$ with an increasing proportion of concentrate in the diet (Table 4). Conversely, apparent whole-tract digestibility of NDF was reduced $(P<0.05)$ with a decreasing $\mathrm{F}: \mathrm{C}$ ratio. Starch digestibility increased linearly $(P<0.01)$, but with a significant quadratic effect $(P<0.05)$ such that there was little difference between the digestibilities at the 3 higher rates of inclusion of concentrate in the diet.

Mean rumen $\mathrm{pH}$ was unaffected by treatment (Table 5). Rumen ammonia $\mathrm{N}$ concentrations were lowest shortly before feeding times, and peaked at about $2 \mathrm{~h}$ after the morning feed and $4 \mathrm{~h}$ after the afternoon feed (Figure 1). Mean ruminal ammonia $\mathrm{N}$ concentrations were affected by treatment $(P<0.05)$, increasing lin-

Table 3. Mean effects of treatment on feed DMI, milk yields, and milk composition of dairy cows offered diets differing in the forage:concentrate $(\mathrm{F}: \mathrm{C})$ ratio $^{1}$

\begin{tabular}{|c|c|c|c|c|c|c|c|}
\hline \multirow[b]{2}{*}{ Item } & \multicolumn{4}{|c|}{$\mathrm{F}: \mathrm{C}$} & \multirow[b]{2}{*}{ SED } & \multicolumn{2}{|c|}{ Significance $^{2}$} \\
\hline & $80: 20$ & $65: 35$ & $50: 50$ & $35: 65$ & & Lin & Quad \\
\hline Mean actual F:C ratio & $80: 20$ & $63: 37$ & $51: 49$ & $39: 61$ & - & - & - \\
\hline \multicolumn{8}{|l|}{ Feed intake, $\mathrm{kg}$ of $\mathrm{DM} / \mathrm{d}$} \\
\hline Silage & 10.5 & 9.8 & 9.3 & 8.1 & 0.63 & $* *$ & NS \\
\hline Concentrate & 2.7 & 5.7 & 9.1 & 12.6 & 0.52 & $* * *$ & $\dagger$ \\
\hline Total feed & 13.2 & 15.5 & 18.4 & 20.7 & 0.85 & $* * *$ & NS \\
\hline $\mathrm{ME}, \mathrm{Mcal} / \mathrm{d}$ & 31.1 & 37.1 & 44.4 & 50.8 & 2.30 & $* * *$ & NS \\
\hline $\mathrm{OM}$ & 12.2 & 14.2 & 16.9 & 19.0 & 0.79 & $* * *$ & NS \\
\hline $\mathrm{N}$ & 0.303 & 0.392 & 0.505 & 0.603 & 0.0264 & $* * *$ & NS \\
\hline NDF & 7.21 & 7.62 & 8.29 & 8.53 & 0.417 & $*$ & NS \\
\hline Starch & 0.55 & 1.15 & 1.87 & 2.57 & 0.126 & $* * *$ & NS \\
\hline Milk yield, kg/d & 17.1 & 18.7 & 20.8 & 24.8 & 0.97 & $* * *$ & $\dagger$ \\
\hline Milk yield/kg of total DMI, $\mathrm{kg} / \mathrm{kg}$ & 1.3 & 1.2 & 1.1 & 1.3 & 0.08 & NS & NS \\
\hline Milk yield/kg of conc. DMI, $\mathrm{kg} / \mathrm{kg}$ & 6.3 & 3.3 & 2.3 & 1.9 & 0.48 & $* * *$ & $*$ \\
\hline \multicolumn{8}{|l|}{ Milk constituent concentration, $\mathrm{g} / \mathrm{kg}$} \\
\hline Fat & 38.5 & 40.7 & 37.2 & 35.0 & 1.56 & * & $\dagger$ \\
\hline $\mathrm{CP}$ & 30.8 & 32.3 & 32.6 & 33.1 & 0.37 & $* * *$ & NS \\
\hline Lactose & 44.5 & 45.4 & 45.4 & 45.9 & 0.41 & $*$ & NS \\
\hline \multicolumn{8}{|l|}{ Milk constituent yield, g/d } \\
\hline Fat & 645 & 753 & 771 & 856 & 39.9 & ** & NS \\
\hline $\mathrm{CP}$ & 512 & 594 & 675 & 793 & 33.3 & $* * *$ & NS \\
\hline Lactose & 767 & 851 & 945 & 1149 & 48.7 & $* * *$ & + \\
\hline
\end{tabular}

${ }^{1}$ Feed intakes, milk yields, and milk composition presented in this table were recorded in the N-partitioning measurement week (wk 3) of each period.

${ }^{2}$ Significance of linear and quadratic treatment effects: $\dagger P<0.1 ; * P<0.05 ; * * P<0.01 ; * * *<0.001$. 
Table 4. Mean effects of treatment on feed digestibility and nutrient flows to the duodenum in cows offered diets differing in the forage:concentrate $(\mathrm{F}: \mathrm{C})$ ratio $^{1}$

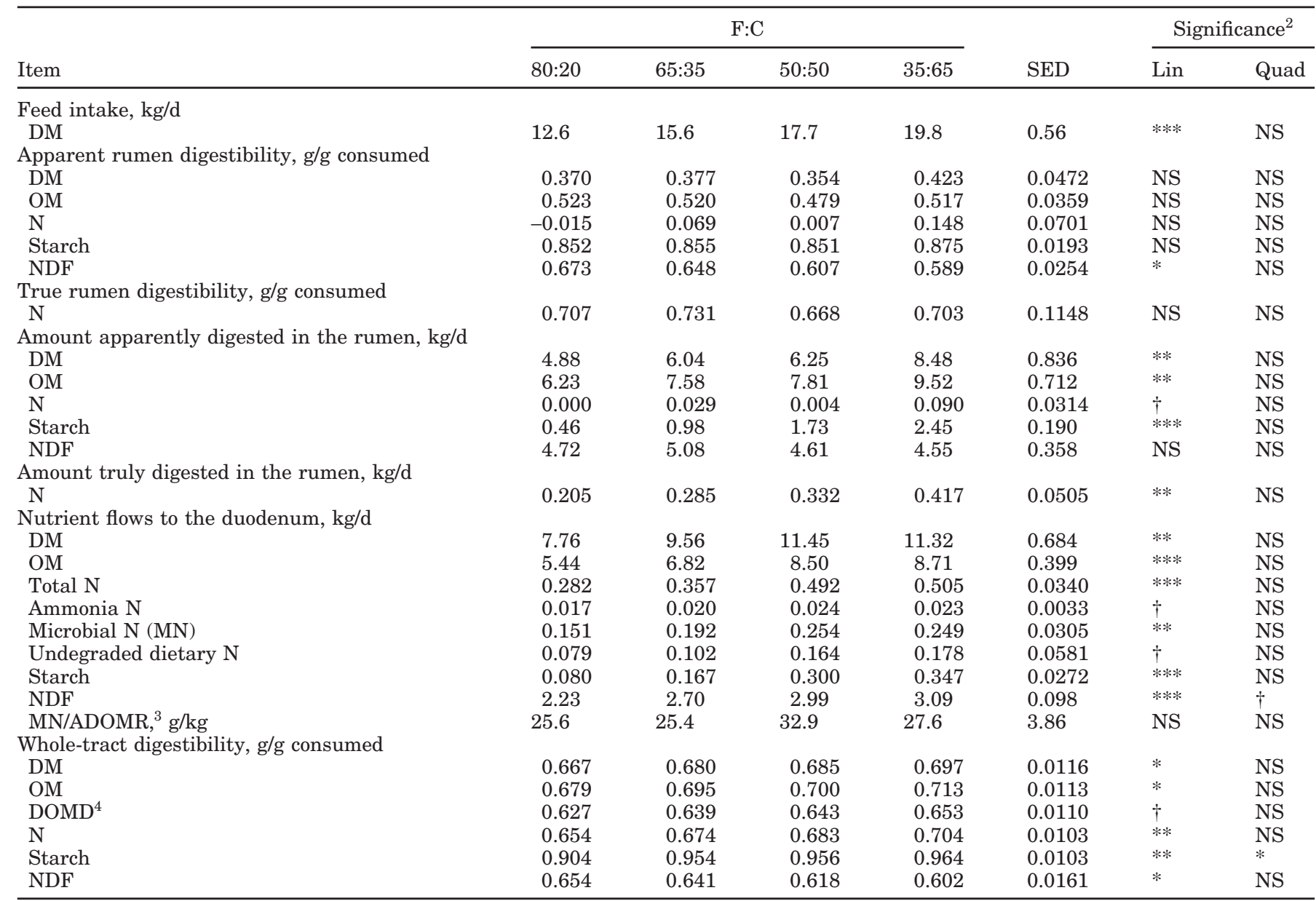

${ }^{1}$ All measurements were taken during the digesta flow week (wk 4 of each period), except whole-tract digestibility data, which were collected during the N-partitioning measurement week (wk 3).

${ }^{2}$ Significance of linear and quadratic treatment effects: $\dagger P<0.1 ; * P<0.05$; ** $P \leq 0.01 ; * * * P<0.001$.

${ }^{3}$ Microbial $\mathrm{N}$ flow per kilogram of OM apparently digested in the rumen.

${ }^{4}$ Digestibility of the OM expressed on a DM basis.

Table 5. Mean effects of treatment on rumen fermentation parameters (mean $\mathrm{pH}$, mean ammonia $\mathrm{N}$ concentrations, and mean molar proportions of VFA averaged across $24 \mathrm{~h}$ ) of cows offered diets differing in the forage:concentrate (F:C) ratio

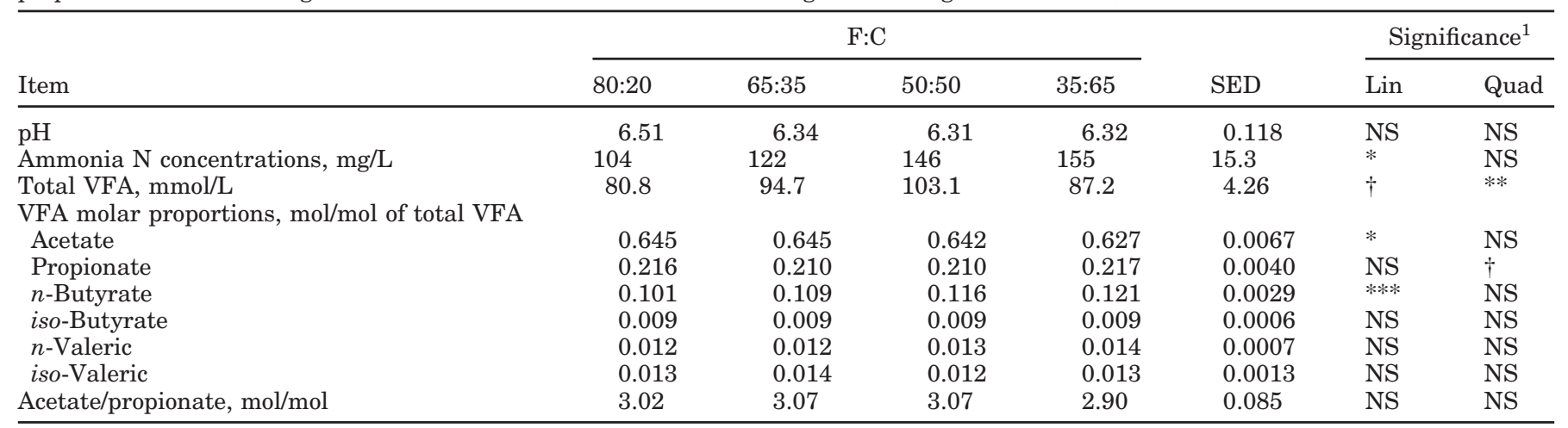

${ }^{1}$ Significance of linear and quadratic treatment effects: $\dagger P<0.1 ; * P<0.05$; ** $P<0.01 ; * * * P<0.001$. 


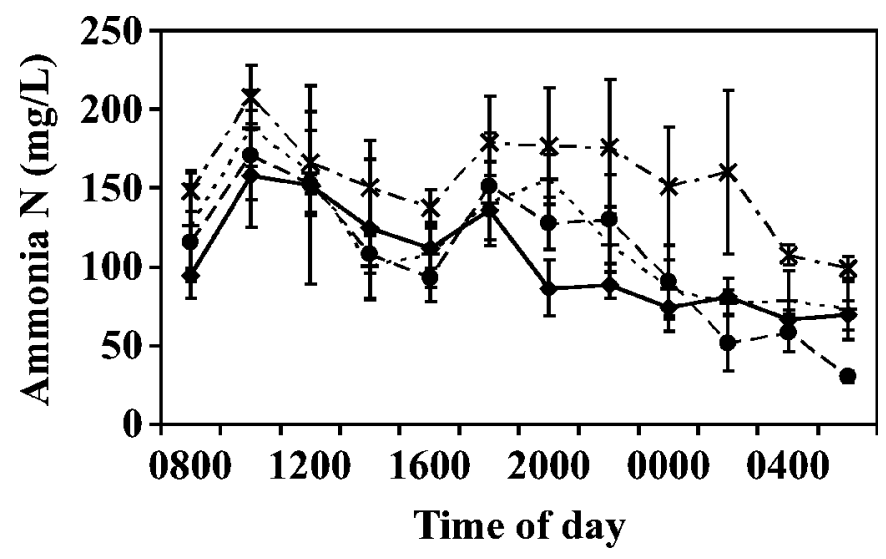

Figure 1. Treatment mean diurnal changes in rumen ammonia $\mathrm{N}$ concentrations of dairy cows offered diets differing in the forage:concentrate ratio $(\bullet, 80: 20 ; \bullet, 65: 35 ;+, 50: 50 ; \times, 35: 65)$. Animals were fed the concentrate portion of their diets at approximately 0800 and $1600 \mathrm{~h}$ each day. Error bars represent SEM values.

early as the proportion of concentrate in the diet increased. There was a significant $(P<0.01)$ quadratic effect of treatment on total VFA concentrations in the rumen, with the highest concentrations in animals consuming the 65:35 and 50:50 diets. The molar proportion of acetate decreased, and the molar proportion of $n$ butyrate increased as the proportion of concentrate in the diet increased $(P<0.05)$. There was no effect of treatment on the molar proportion of propionate and other VFA, or on the acetate:propionate ratio in the rumen.

\section{$P D$ and Creatinine Excretion}

Urinary excretion of PD was increased $(P<0.001)$ with a decreasing $\mathrm{F}: \mathrm{C}$ ratio, with the highest rates of excretion of both allantoin and uric acid at the highest proportions of concentrate in the diet (Table 6). The linear relationship between total PD excretion (allantoin + uric acid; $\mathrm{mmol} / \mathrm{d}$ ) and microbial $\mathrm{N}$ flow to the duodenum (based on cytosine flow; g/d) was computed as: microbial $\mathrm{N}=19.9+0.689 \times$ total $\mathrm{PD}, \mathrm{r}^{2}=0.787$

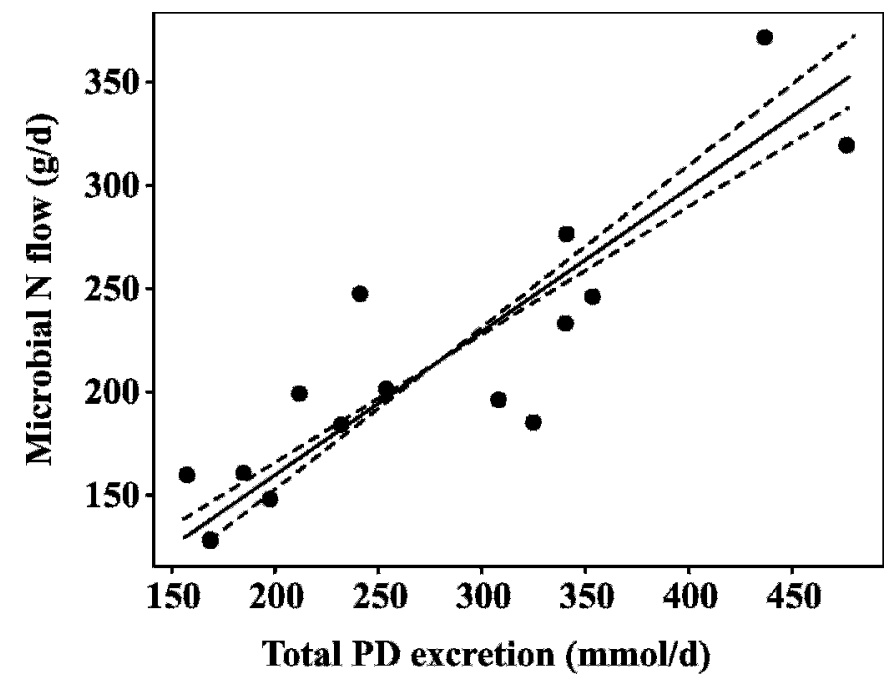

Figure 2. Functional relationship between total purine derivative (PD; allantoin plus uric acid) excretion in urine and microbial $\mathrm{N}$ flow to the duodenum in cows $(\mathrm{n}=16)$ offered diets differing in the forage:concentrate ratio. Microbial N $(\mathrm{g} / \mathrm{d})=19.9+0.689 \times$ total PD $(\mathrm{mmol} / \mathrm{d}) ; \mathrm{r}^{2}=0.787$. The 2 dotted lines indicate the absolute upper and lower limits of the functional relationship slope (solid line).

(Figure 2). The correlation coefficient between DMI and microbial $\mathrm{N}$ flow to the duodenum was $\mathrm{r}=0.609$, and between DMI and total urinary PD excretion was $\mathrm{r}=$ 0.707 . Creatinine excretion in the urine was not affected by treatment, with an overall mean excretion rate of $113.3 \mathrm{mmol} / \mathrm{d}$. Daily excretion of creatinine on a BW basis was similarly unaffected, with an overall mean of $19.3 \mathrm{mg} / \mathrm{kg}$ of BW per $\mathrm{d}$.

\section{Nitrogen Partitioning}

Nitrogen intake was increased $(P<0.001)$ with a decreasing $\mathrm{F}: \mathrm{C}$ ratio (Table 7), coupled with concomitant increases in the daily rates of excretion of $\mathrm{N}$ in urine and feces, and secretion of $\mathrm{N}$ in milk. When expressed as a proportion of $\mathrm{N}$ intake, urine $\mathrm{N}$ output was not affected by treatment, although feces excretion $(P<0.01)$ and milk N secretion $(P<0.05)$ both decreased with decreasing $\mathrm{F}: \mathrm{C}$ ratios.

Table 6. Mean effects of treatment on purine derivative (PD) and creatinine excretion in urine (mmol/d) from cows offered diets differing in the forage:concentrate $(\mathrm{F}: \mathrm{C})$ ratio

\begin{tabular}{lcccccc}
\hline & \multicolumn{3}{c}{ F:C } & & \multicolumn{1}{c}{ Significance, ${ }^{1}$} \\
\cline { 2 - 5 } Item & $80: 20$ & $65: 35$ & $50: 50$ & $35: 65$ & SED & Lin \\
\hline Allantoin & 182 & 181 & 298 & 303 & 24.9 & $* * *$ \\
Uric acid & 14.8 & 17.8 & 35.8 & 39.2 & 3.41 & $* * *$ \\
Total PD & 197 & 199 & 334 & 370 & 26.6 & $* * *$ \\
Creatinine & 137 & 96 & 113 & 107 & 20.9 & NS \\
\hline
\end{tabular}

${ }^{1}$ Significance of linear treatment effects: $* * * P<0.001$. There were no significant quadratic treatment effects. 
Table 7. Mean treatment effects on $\mathrm{N}$ outputs and on whole-body $\mathrm{N}$ partitioning in cows offered diets differing in the forage:concentrate $(\mathrm{F}: \mathrm{C})$ ratio

\begin{tabular}{|c|c|c|c|c|c|c|}
\hline \multirow[b]{2}{*}{ Item } & \multicolumn{4}{|c|}{$\mathrm{F}: \mathrm{C}$} & \multirow[b]{2}{*}{ SED } & \multirow{2}{*}{$\begin{array}{l}\text { Significance, }{ }^{1} \\
\text { Lin }\end{array}$} \\
\hline & $80: 20$ & $65: 35$ & $50: 50$ & $35: 65$ & & \\
\hline $\mathrm{N}$ intake, $\mathrm{g} / \mathrm{d}$ & 303 & 392 & 505 & 603 & 26.4 & $* * *$ \\
\hline \multicolumn{7}{|l|}{$\mathrm{N}$ output, $\mathrm{g} / \mathrm{d}$} \\
\hline Urine & 74 & 79 & 145 & 137 & 20.5 & $* *$ \\
\hline Feces & 105 & 128 & 161 & 178 & 8.7 & $* * *$ \\
\hline Milk & 78 & 92 & 105 & 126 & 6.9 & $* * *$ \\
\hline \multicolumn{7}{|c|}{$\mathrm{N}$ partitioning, $\mathrm{g}$ of $\mathrm{N}$ out/g of $\mathrm{N}$ intake } \\
\hline Urine & 0.25 & 0.21 & 0.29 & 0.23 & 0.046 & NS \\
\hline Feces & 0.35 & 0.33 & 0.32 & 0.30 & 0.010 & $* *$ \\
\hline Milk & 0.26 & 0.24 & 0.21 & 0.21 & 0.022 & * \\
\hline
\end{tabular}

\footnotetext{
${ }^{1}$ Significance of linear treatment effects: $* P<0.05 ; * * P<0.01 ; * * P<0.001$. There were no significant
} quadratic treatment effects.

\section{DISCUSSION}

\section{Feed Intake and Milk Production}

Total feed DMI increased (57\%) as the proportion of concentrate in the diet increased. This was despite a significant (more than $2 \mathrm{~kg} / \mathrm{d}$ ) reduction in silage intake (-33\%), although this was far outweighed by the (366\%) increase in concentrate intake. Increased total DMI is often (Sloan et al., 1988; Friggens et al., 1998a; Kuoppala et al., 2004), but not always (Hansen et al., 1991), found when the concentrate portion of a dairy cow's diet is increased, and a substitution effect is frequently obtained with large changes in the $\mathrm{F}: \mathrm{C}$ ratio. As a result of the relatively low quality of grass silage, the effect of concentrate intake in terms of a reduction of silage intake was quantitatively less important than the additive effect of concentrate intake, leading to greater total DMI at the high inclusion rates of concentrate in the diet, as indicated by Broster and Thomas (1981).

The high CP concentration of the concentrate feed meant that the $\mathrm{N}$ intake of cows offered the 35:65 diet was twice that of those offered the 80:20 diet, whereas the much lower NDF concentration of the concentrate compared with the silage meant that the intake of NDF was only marginally increased. There was a nearly 5fold difference in starch intake between animals on the 2 extreme diets, which was supplied completely by the concentrate portion of the diet. The consequence of increased feed intake with increasing concentrate inclusion in the diet was a significant increase in milk yield (of $7.7 \mathrm{~kg} / \mathrm{d}$, or $45 \%$ in proportional terms). This was expected, because increased milk yields are a common (Hansen et al., 1991; Rinne et al., 1999; Yang et al., 2001), but not inevitable (Kuoppala et al., 2004), result of increasing the proportion of concentrate in the diet. Similarly, milk protein concentration is often found to be increased as concentrate intake increases (Mayne and Gordon, 1984; Rinne et al., 1999; Yang et al., 2001), as was found in the present study. Increased milk protein yields are likely a result of increased absorption of AA from the high concentrate-high starch intake diets (Huntington and Reynolds, 1986; Huntington, 1989) that are required for milk protein synthesis.

The milk fat yield increased with an increasing proportion of concentrate in the diet, but at a rate that was not as great as the concomitant increase in milk yields, so that the concentration of milk fat was reduced. This modest milk fat depression was statistically significant $(P<0.05)$. The biohydrogenation theory of milk fat depression (Griinari et al., 1998) suggests that milk fat depression is the result of fatty acid biohydrogenation intermediates, such as trans-10,cis-12 conjugated linoleic acid and trans-10 18:1, and not VFA supply. There was no difference in average concentrations of acetate plus butyrate in rumen liquor with these diets, and the modest milk fat depression was associated with an increased yield of trans-10 18:1 fatty acid in milk (R. J. Dewhurst (IGER), B. Vlaeminck (Ghent Univ., Belgium), and V. Fievez (Ghent Univ., Belgium), unpublished data from the current study), which agrees with the results of Griinari et al. (1998).

\section{Feed Digestibility, Rumen Fermentation, and Digesta Flows}

Diet digestibility increased as the proportion of concentrate in the diet increased, with most of the increases in digestibility occurring postruminally. As intake increased, microbial $\mathrm{N}$ flows to the duodenum increased and the flow of nutrients from the rumen to the duodenum increased for all components. This lack of treatment effect on apparent rumen digestibility of OM, but increased apparent whole-tract OM digestibility with decreasing $\mathrm{F}: \mathrm{C}$, concurs with the results of others (Sarwar et al., 1992; Yang et al., 2001). This is in contrast to the apparent rumen digestibility of starch, 
which was unaffected by diet in the present experiment but was found by others to decrease with high-fiber diets (Yang et al., 2001). At the same time, apparent whole-tract digestibility of starch increased with higher concentrate intakes in the current study, whereas this was previously found to be unaffected by diet fiber content (Yang et al., 2001). Although apparent rumen and whole-tract digestibilities of starch in all treatments in the present study were substantially higher than those found by Yang et al. (2001), the starch intakes by animals in that experiment were approximately double those in the present experiment, and starch duodenal flow was almost 10 times greater than the highest mean value observed in this experiment. Differences between experiments may therefore be a result of differences in the relative transit time of starch through the rumen and rate of passage through the rest of the gut.

Assuming an endogenous N contribution of $2.8 \mathrm{~g} / \mathrm{kg}$ of DMI (Bartram, 1987), true rumen digestibility of feed $\mathrm{N}$ was considerable but was unaffected by dietary treatment. The apparent rumen digestion of $\mathrm{N}$ was unaffected by diet, with average values close to zero. Much of the $\mathrm{N}$ released from feed through rumen fermentation was incorporated into microbial protein, which flowed out to the duodenum together with undegraded feed N. Nitrogen absorbed directly from the rumen and other stomach tissues into the body was apparently balanced by the recycling of $\mathrm{N}$ from the body back into the rumen, either across the rumen wall or via saliva (Huntington, 1989). Therefore, the net difference between $\mathrm{N}$ consumption and $\mathrm{N}$ flow to the duodenum was close to zero. Whole-tract digestibility of $\mathrm{N}$ was similar to previous reports (Mayne and Gordon, 1984; Sarwar et al., 1992), and the slight increase in digestibility with a decreasing $\mathrm{F}: \mathrm{C}$ ratio reflects the change in diet protein quality as concentrate $\mathrm{CP}$ intake increased and silage $\mathrm{CP}$ intake decreased. No attempt was made to maintain diet CP concentration or quality across the four diets, and the increase in CP and starch intakes between the low-concentrate (80:20) and high-concentrate (35:65) diets was highly significant.

Apparent rumen and whole-tract fiber digestibility were significantly decreased with a decreasing $\mathrm{F}: \mathrm{C}$ ratio, although the amount of fiber digested in the rumen on a daily basis was not affected by dietary treatment, and fiber digestibility may therefore have been reduced as a result of increased passage rates as feed intakes increased.

Excessively low rumen $\mathrm{pH}$ can be a problem in dairy cows consuming a diet with high proportions of concentrates or cereal grains, when acid production exceeds the buffering capacity of the rumen; in particular, fiber digestion can be compromised at $\mathrm{pH} 6$ or less (Mould and Ørskov, 1983; Robinson et al., 1987). In the present study, sodium bicarbonate was fed as part of the diet specifically to prevent acidotic conditions, and this was successful because rumen $\mathrm{pH}$ was unaffected by diet and had only limited fluctuations during the day. Mean rumen $\mathrm{pH}$ was always above 6.2 .

Rumen ammonia $\mathrm{N}$ concentrations varied in response to feeding, with peaks occurring 2 to $4 \mathrm{~h}$ after each concentrate meal, concurring with previous results (Gustafsson and Palmquist, 1993). The mean ammonia $\mathrm{N}$ concentration stayed above the value of approximately $50 \mathrm{mg} / \mathrm{L}$ required to allow maximum microbial growth in the rumen (Slyter et al., 1979) for all measurements, apart from the animals on the 65:35 diet at $0600 \mathrm{~h}$. Perhaps for this reason, together with the lack of treatment differences in apparent rumen digestibility of $\mathrm{OM}$, there was no difference among treatments in the efficiency of microbial $\mathrm{N}$ production per unit of $\mathrm{OM}$ apparently digested in the rumen as feed intake increased. Rumen ammonia $\mathrm{N}$ concentrations increased significantly, or tended to increase, with a decreasing F:C ratio as the protein concentration of the whole diet increased, an effect also reported by others (Mayne and Gordon, 1984) even when the N concentrations of diets with differing F:C ratios were similar (Carro et al., 2000). In the present study, the concentrate $\mathrm{N}$ concentration was approximately double that of the silage $\mathrm{N}$ concentration, so the total diet $\mathrm{N}$ concentration increased as the proportion of concentrate in the diet increased. As the proportion of concentrate in the diet increased, the amount of $\mathrm{N}$ truly digested in the rumen increased, which is likely to be the main reason for increased rumen ammonia $\mathrm{N}$ concentrations.

The concentration of total VFA in the rumen fluid remained relatively stable as the proportion of concentrate in the diet increased. The molar proportion of propionate was not affected by dietary treatment, but the relative proportions of acetate and butyrate decreased and increased, respectively, as the proportion of concentrate in the diet increased. Supplementation of forage with concentrates is frequently found to lead to increased molar proportions of propionate in the rumen, although this did not happen in the current study. However, the molar proportions of rumen propionate in this study are at the lower end of the range reported in the literature, and this may have been related to the lactic acid concentration of the grass silage (Martin et al., 1994), which was the same for all diets, unlike the F:C ratio. Our results agree with those of Friggens et al. (1998b), who found that increasing the proportion of wheat in a diet based on grass silage led to a reduction in the molar proportion of acetate and a concomitant increase in the molar proportion of butyrate with no effect on proportions of propionate. Murphy et al. (2000) found a similar lack of effect on molar proportions of 
propionate in the rumen when changing the $\mathrm{F}: \mathrm{C}$ ratio from 30:70 to 50:50 in dairy cow diets based on both grass hay and grass silage. Chamberlain et al. (1983) found the molar proportion of propionate in the rumen to decrease when grass silages were supplemented with barley, and suggested that this was linked to the rumen fermentation of lactic acid supplied by the silage.

\section{$P D$ and Creatinine Excretion}

A number of workers (Puchala and Kulasek, 1992; Johnson et al., 1998; González-Ronquillo et al., 2004) have used urinary PD excretion to estimate microbial $\mathrm{N}$ flow to the duodenum in ruminants, with a strong positive correlation between the two. Using data from a number of experiments with cows at various stages of lactation, Johnson et al. (1998) found that microbial $\mathrm{N}$ flow to the duodenum was neither consistently nor significantly related to allantoin excretion in urine, but its relationship with uric acid excretion was better. In this study, a strong positive linear relationship was found between microbial $\mathrm{N}$ flow to the duodenum and total PD excretion; this was expected because microbial $\mathrm{N}$ was estimated using the purine content of duodenal digesta, which has been shown to be well correlated with urinary PD excretion in dairy cows (Vagnoni et al., 1997; González-Ronquillo et al., 2003). The results of this study confirm the earlier observations, and large changes in the diet $\mathrm{F}: \mathrm{C}$ ration do not seem to have affected the relationship between microbial $\mathrm{N}$ flow to the duodenum and urinary PD excretion because it was linear throughout the range observed in the current experiment. In the present study, there were also strong positive correlations between total DMI and microbial $\mathrm{N}$ flow to the duodenum, and total DMI and total urinary PD excretion, which were to be expected.

Creatinine excretion, both on a daily basis and on a BW basis, was not significantly affected by diet, which confirms previous reports of studies varying the proportion of concentrate in ruminant diets (Coto et al., 1988; Gonda et al., 1996; Valadares et al., 1999). The assumption that creatinine is excreted at a constant rate is widely accepted and creatinine is frequently used as a urine volume marker in clinical applications. However, the daily rate of excretion of creatinine $(\mathrm{mg} / \mathrm{kg}$ of BW/ d) from the animals in the current study was approximately two-thirds that reported by Valadares et al. (1999) but was similar to that reported by Gonda et al. (1996), and may be related to differences in the proportion of lean body tissue in the animals used in the 2 studies, because creatinine excretion is related to body protein mass turnover. This limits the use of spot urine samples for estimating microbial protein yield from the rumen (in which urinary PD excretion is measured in proportion to creatinine concentration) to applications in which a relative measurement is sufficient.

\section{Whole-Body Nitrogen Partitioning}

Nitrogen outputs, in urine, feces, and milk, all increased as $\mathrm{N}$ intake increased with increasing feed intake. Despite this, $\mathrm{N}$ excreted in the urine, expressed as a proportion of feed $\mathrm{N}$ intake, was not significantly affected by dietary treatment. Urinary $\mathrm{N}$ excretion is a factor of the absorption of ammonia $\mathrm{N}$ from the rumen and recycling of that $\mathrm{N}$ back into the gut, which is in turn related to the composition of the animal's diet and the efficiency with which dietary $\mathrm{N}$ is used in the rumen. The ratio of total $\mathrm{N}$ flow to the duodenum to $\mathrm{N}$ consumed was constant across treatments, indicating that the net loss of $\mathrm{N}$ from the rumen was also constant across treatments, and therefore urine $\mathrm{N}$ excretion as a proportion of feed $\mathrm{N}$ intake was similar for all diets. As wholetract $\mathrm{N}$ digestibility increased with a decreasing $\mathrm{F}: \mathrm{C}$ ratio, the proportion of dietary $\mathrm{N}$ excreted in feces was reduced, although in absolute terms the quantities of feces $\mathrm{N}$ and urine $\mathrm{N}$ excreted increased as feed intake increased. Similarly, milk N output increased as milk yield increased, although the efficiency with which feed $\mathrm{N}$ was used for milk production (milk $\mathrm{N}$ output/feed $\mathrm{N}$ intake) was reduced with a decreasing $\mathrm{F}: \mathrm{C}$ ratio.

In conclusion, increasing the proportion of concentrate in grass silage-based diets of midlactation dairy cows significantly increased feed (and energy) intakes, which led to increased milk output. The production of microbial $\mathrm{N}$ per unit of organic matter apparently digested in the rumen was similar for all diets, so that increased microbial $\mathrm{N}$ yields from the duodenum were observed, although differences in the relative rates of supply of nutrients for the synthesis of milk components (AA for protein and glucose for lactose) may have resulted from increased rates of glucose uptake from the gut following the digestion of bypass starch. A strong positive linear relationship between microbial purine flow in the duodenum and urinary output was found, which strengthens the case for using urinary PD as a noninvasive marker to estimate microbial protein flow from the rumen.

\section{ACKNOWLEDGMENTS}

We wish to thank L. J. Davies and V. J. Theobald for care of the animals; J. K. S. Tweed, P. Rees-Stevens, and S. J. Youell for analysis of the samples; and W. M. Hirst and M. S. Dhanoa for advice on statistical analysis of the data. This work was funded by the UK Ministry of Agriculture, Fisheries and Food (now the Department for Environment, Food and Rural Affairs). 


\section{REFERENCES}

Agricultural and Food Research Council (AFRC). 1993. Energy and Protein Requirements of Ruminants [an Advisory Manual prepared by the AFRC Technical Committee on Responses to Nutrients]. CAB International, Wallingford, UK.

Bartlett, M. S. 1949. Fitting of straight lines when both variables are subject to error. Biometrics 5:207-212.

Bartram, C. G. 1987. The Endogenous Protein Content of Ruminant Proximal Duodenal Digesta. University of Nottingham, Nottingham, UK.

Broster, W. H., and C. Thomas. 1981. The influence of level and pattern of concentrate input on milk output. Pages 49-69 in Recent Advances in Animal Nutrition. W. Haresign, ed. Butterworths, London.

Carro, M. D., C. Valdes, M. J. Ranilla, and J. S. Gonzalez. 2000. Effect of forage to concentrate ratio in the diet on ruminal fermentation and digesta flow kinetics in sheep offered food at a fixed and restricted level of intake. Anim. Sci. 70:127-134.

Chamberlain, D. G., P. C. Thomas, and F. J. Anderson. 1983. Volatile fatty acid proportions and lactic acid metabolism in the rumen in sheep and cattle receiving silage diets. J. Agric. Sci. (Cambridge) 101:47-58.

Coto, G., M. M. Rodriguez, F. Perez Infante, P. Melgarez, and M. Perez. 1988. The effect of increasing consumption of concentrates creatinine, creatine and allantoin in the urine of rams fed hay. Cuba. J. Agric. Sci. 22:279-284.

Cozzi, G., G. Bittante, and C. E. Polan. 1993. Comparison of fibrous materials as modifiers of in situ ruminal degradation of corn gluten meal. J. Dairy Sci. 76:1106-1113.

Dewhurst, R. J., D. R. Davies, and R. J. Merry. 2000a. Microbial protein supply from the rumen. Anim. Feed Sci. Technol. 85:1-21.

Dewhurst, R. J., R. T. Evans, N. D. Scollan, J. M. Moorby, R. J. Merry, and R. J. Wilkins. 2003. Comparison of grass and legume silages for milk production. 2. In vivo and in sacco evaluations of rumen function. J. Dairy Sci. 86:2612-2621.

Dewhurst, R. J., A. M. Mitton, N. W. Offer, and C. Thomas. 1996. Effects of the composition of grass silages on milk production and nitrogen utilization by dairy cows. Anim. Sci. 62:25-34.

Dewhurst, R. J., J. M. Moorby, M. S. Dhanoa, R. T. Evans, and W. J. Fisher. 2000b. Effects of altering energy and protein supply to dairy cows during the dry period. 1 . Intake, body condition, and milk production. J. Dairy Sci. 83:1782-1794.

Faichney, G. J. 1980. The use of markers to measure digesta flow from the stomach of sheep fed once daily. Journal of Agricultural Science, Cambridge. 94:313-318.

Friggens, N. C., G. C. Emmans, I. Kyriazakis, J. D. Oldham, and M. Lewis. 1998a. Feed intake relative to stage of lactation for dairy cows consuming total mixed diets with a high or low ratio of concentrate to forage. J. Dairy Sci. 81:2228-2239.

Friggens, N. C., J. D. Oldham, R. J. Dewhurst, and G. Horgan. 1998b. Proportions of volatile fatty acids in relation to the chemical composition of feeds based on grass silage. J. Dairy Sci. 81:1331-1344.

Gonda, H. L., M. Emanuelson, and M. Murphy. 1996. The effect of roughage to concentrate ratio in the diet on nitrogen and purine metabolism in dairy cows. Anim. Feed Sci. Technol. 64:27-42.

González-Ronquillo, M., J. Balcells, A. Belenguer, C. Castrillo, and M. Mota. 2004. A comparison of purine derivatives excretion with conventional methods as indices of microbial yield in dairy cows. J. Dairy Sci. 87:2211-2221.

González-Ronquillo, M., J. Balcells, J. A. Guada, and F. Vicente. 2003. Purine derivative excretion in dairy cows: Endogenous excretion and the effect of exogenous nucleic acid supply. J. Dairy Sci. 86:1282-1291.

Griinari, J. M., D. A. Dwyer, M. A. McGuire, D. E. Bauman, D. L. Palmquist, and K. V. V. Nurmela. 1998. Trans-octadecenoic acids and milk fat depression in lactating dairy cows. J. Dairy Sci. $81: 1251-1261$

Gustafsson, A. H., and D. L. Palmquist. 1993. Diurnal variation of rumen ammonia, serum urea, and milk urea in dairy cows at high and low yields. J. Dairy Sci. 76:475-484.
Hansen, W. P., D. E. Otterby, J. G. Linn, and J. D. Donker. 1991. Influence of forage type, ratio of forage to concentrate, and methionine hydroxy analog on performance of dairy cows. J. Dairy Sci. 74:1361-1369.

Huntington, G. B. 1989. Hepatic urea synthesis and site and rate of urea removal from blood of beef steers fed alfalfa hay or a high concentrate diet. Can. J. Anim. Sci. 69:215-223.

Huntington, G. B., and P. J. Reynolds. 1986. Net absorption of glucose, L-lactate, volatile fatty acids, and nitrogenous compounds by bovine given abomasal infusions of starch or glucose. J. Dairy Sci. 69:2428-2436.

Johnson, L. M., J. H. Harrison, and R. E. Riley. 1998. Estimation of the flow of microbial nitrogen to the duodenum using urinary uric acid or allantoin. J. Dairy Sci. 81:2408-2420.

Kuoppala, K., S. Yrjänen, S. Jaakkola, R. Kangasniemi, J. Sariola, and H. Khalili. 2004. Effects of increasing concentrate energy supply on the performance of loose-housed dairy cows fed grass silage-based diets. Livest. Prod. Sci. 85:15-26.

Lawes Agricultural Trust. 2000. Genstat 5 for Windows. 4.2 ed. Numerical Algorithms Group, Oxford, UK.

Martin, P. A., D. G. Chamberlain, S. Robertson, and D. Hirst. 1994. Rumen fermentation patterns in sheep receiving silages of different chemical composition supplemented with concentrates rich in starch or in digestible fiber. J. Agric. Sci. (Camb.) 122:145-150.

Mayne, C. S., and F. J. Gordon. 1984. The effect of type of concentrate and level of concentrate feeding on milk production. Anim. Prod. 39:65-76.

McAllan, A. B. 1980. The degradation of nucleic acid in, and the removal of breakdown products from the small intestine of steers. Br. J. Nutr. 44:99-112.

McAllan, A. B., and R. H. Smith. 1973. Degradation of nucleic acid derivatives by rumen bacteria in vitro. Br. J. Nutr. 29:467-474.

Moorby, J. M., R. J. Dewhurst, J. K. S. Tweed, M. S. Dhanoa, and N. F. G. Beck. 2000. Effects of altering the energy and protein supply to dairy cows during the dry period. 2. Metabolic and hormonal responses. J. Dairy Sci. 83:1795-1805.

Mould, F. L., and E. R. Ørskov. 1983. Manipulation of rumen fluid $\mathrm{pH}$ and its influence on cellulolysis in sacco, dry matter degradation and the rumen microflora of sheep offered either hay or concentrate. Anim. Feed Sci. Technol. 10:1-14.

Murphy, M., M. Åkerlind, and K. Holtenius. 2000. Rumen fermentation in lactating cows selected for milk fat content fed two forage to concentrate ratios with hay or silage. J. Dairy Sci. 83:756-764.

NRC (National Research Council). 2001. Nutrient Requirements of Dairy Cattle. 7th rev. ed. National Academy Press, Washington, DC.

Puchala, R., and G. W. Kulasek. 1992. Estimation of microbial protein flow from the rumen of sheep using microbial nucleic acid and urinary excretion of purine derivatives. Can. J. Anim. Sci. 72:821-830.

Rinne, M., S. Jaakkola, K. Kaustell, T. Heikkila, and P. Huhtanen. 1999. Silages harvested at different stages of grass growth $\mathrm{v}$. concentrate foods as energy and protein sources in milk production. Anim. Sci. 69:251-263.

Robinson, P. H., S. Tamminga, and A. M. van Vuuren. 1987. Influence of declining level of feed intake and varying the proportion of starch in the concentrate on rumen ingesta quantity, composition and kinetics of ingesta turnover in dairy cows. Livest. Prod. Sci. $17: 37-62$.

Sarwar, M., J. L. Firkins, and M. L. Eastridge. 1992. Effects of varying forage and concentrate carbohydrates on nutrient digestibilities and milk production by dairy cows. J. Dairy Sci. 75:1533-1542.

Siddons, R. C., J. Paradine, D. E. Beever, and P. R. Cornell. 1985. Ytterbium acetate as a particulate phase digesta flow marker. Br. J. Nutr. 54:509-519.

Sloan, B. K., P. Rowlinson, and D. G. Armstrong. 1988. Milk production in early lactation dairy cows given grass silage ad libitum: Influence of concentrate energy source, crude protein content and level of concentrate allowance. Anim. Prod. 46:317-331. 
Slyter, L. L., L. D. Satter, and D. A. Dinius. 1979. Effect of ruminal ammonia concentration on nitrogen utilisation by steers. J. Anim. Sci. 48:906-912.

Titgemeyer, E. C. 1997. Design and interpretation of nutrient digestion studies. J. Anim. Sci. 75:2235-2247.

Vagnoni, D. B., G. A. Broderick, M. K. Clayton, and R. D. Hatfield. 1997. Excretion of purine derivatives by Holstein cows abomasally infused with incremental amounts of purines. J. Dairy Sci. 80:1695-1702.
Valadares, R. F. D., G. A. Broderick, S. C. Valadares, and M. K. Clayton. 1999. Effect of replacing alfalfa silage with high moisture corn on ruminal protein synthesis estimated from excretion of total purine derivatives. J. Dairy Sci. 82:2686-2696.

Yang, W. Z., K. A. Beauchemin, and L. M. Rode. 2001. Effects of grain processing, forage to concentrate ratio, and forage particle size on rumen $\mathrm{pH}$ and digestion by dairy cows. J. Dairy Sci. $84: 2203-2216$. 